\title{
Nutrient Content and Uptake by Wheat (Triticum aestivum L) as Influenced by Iron and Zinc Enriched FYM in Salt Affected Soils of Gujarat
}

\author{
J.K. Malav ${ }^{*}$, N.N. Salvi ${ }^{2}$, J.K. Patel ${ }^{1}$, J.R. Jat ${ }^{3}$, S. Kumar ${ }^{3}$, R.P. Pavaya ${ }^{1}$, \\ B.T. Patel ${ }^{1}$ and V.R. Patel ${ }^{1}$
}

${ }^{1}$ Department of Agricultural Chemistry \& Soil Science, C.P. College of Agriculture, S.D. Agricultural University, Sardarkrushinagar-385 506 (Gujarat), India

${ }^{2}$ Agricultural Research Station, S.D. Agricultural University, Adiya, Gujarat, India

${ }^{3}$ Agroforestry Research Centre, S.D. Agricultural University, Sardarkrushinagar, Gujarat, India

*Corresponding author

\section{Keywords \\ Wheat, Nutrient, Content, Uptake, FYM}

Article Info

Accepted:

24 May 2019

Available Online:

10 June 2019

\section{A B S T R A C T}

A field experiment was conducted for 4 successive years, consisting of eight treatments laid out in randomized block design to evaluate the nutrient content and uptake by wheat (Triticum aestivum L) as influenced by iron and zinc enriched FYM on salt affected soils of Gujarat. The results reveal that application of recommended dose of fertilizer (120-60$00 \mathrm{NPK} \mathrm{kg} \mathrm{ha}{ }^{-1}$ ) on the basis of STV + 0.5 $\mathrm{t} \mathrm{FYM} \mathrm{ha}^{-1}$ enriched with $0.75 \mathrm{~kg} \mathrm{Zn}$ and 1.5 $\mathrm{kg} \mathrm{Fe}\left(\mathrm{T}_{8}\right)$ recorded significantly higher grain and straw yields of wheat over $\mathrm{T}_{1}$ (Recommended dose of fertilizer on the basis of STV only) on pooled basis. Significantly higher nitrogen $(2.41 \%)$, phosphorus $(0.33 \%)$ and iron $\left(59.07 \mathrm{mg} \mathrm{kg}^{-1}\right)$ content in grain and highest nitrogen $(1.09 \%)$, phosphorus $(0.173 \%)$, potassium $(1.32 \%)$, iron $\left(265.2 \mathrm{mg} \mathrm{kg}^{-1}\right)$ and zinc $\left(42.75 \mathrm{mg} \mathrm{kg}^{-1}\right)$ content in wheat straw were observed with the application of RDF (based on STV) along with $0.5 \mathrm{t} \mathrm{FYM} \mathrm{ha}^{-1} \mathrm{En}$. with $0.75 \mathrm{~kg} \mathrm{Zn}$ and $1.5 \mathrm{~kg} \mathrm{Fe}$ on pooled basis. While, significantly higher potassium content in wheat grain was observed with the application of recommended dose of fertilizer (120-60-00 NPK kg ha ${ }^{-1}$ ) on the basis of STV+1.0 t FYM ha ${ }^{-1}\left(\mathrm{~T}_{5}\right)$ on pooled basis. The results revealed that significantly maximum nitrogen (119.82 and $84.97 \mathrm{~kg} \mathrm{ha}^{-1}$ ), phosphorus (16.25 and $\left.14.02 \mathrm{~kg} \mathrm{ha}^{-1}\right)$, potassium (31.54 and $104.2 \mathrm{~kg} \mathrm{ha}^{-1}$ ) and iron (305.8 and $\left.2098 \mathrm{~g} \mathrm{ha}^{-1}\right)$ uptake by wheat grain and straw was recorded under treatment $\mathrm{T}_{8}\left(\mathrm{~T}_{1}+0.5 \mathrm{t} \mathrm{FYM} \mathrm{ha}^{-1} \mathrm{En}\right.$. with $0.75 \mathrm{~kg} \mathrm{Zn}$ and $1.5 \mathrm{~kg} \mathrm{Fe})$ on pooled basis; but in case of zinc uptake by wheat grain $\left(88.88 \mathrm{~g} \mathrm{ha}^{-1}\right)$ was higher under treatment $\mathrm{T}_{5}\left(\mathrm{~T}_{1}+1.5 \mathrm{~kg} \mathrm{Zn}+3.0 \mathrm{~kg} \mathrm{Fe} \mathrm{ha}^{-1}\right)$ on pooled basis.

\section{Introduction}

Wheat is the prevailing grain crop of the world commerce. It is occupying a significant ingredient of the daily diet of millions of people. It plays an imperative role in human diet and also provides a strong monetary support of the country (Singh et al., 2012). In high input agriculture, deficiency of micronutrients has become major constraint to 
productivity, stability and sustainability of soils. These deficiencies appeared much faster primarily due to the fast adoption of new agricultural technology, including cultivation of high yielding crop varieties, increase in cropping intensity, expansion of irrigation facilities, more use of high analysis fertilizers and poor quality irrigation water. Among micronutrients, $\mathrm{Zn}$ is now being regarded as the third most limiting nutrient element in crop production after $\mathrm{N}$ and $\mathrm{P}$. The extent of $\mathrm{Fe}$ deficiency in India is next to the $\mathrm{Zn}$. About $11 \%$ of Indian soils are deficient in iron and recently Mn has become critical. Cereal crops are inherently very low in grain $\mathrm{Zn}$ and $\mathrm{Fe}$ concentrations and growing them on potentially $\mathrm{Zn}$ and $\mathrm{Fe}$ deficient soils further reduces $\mathrm{Fe}$ and $\mathrm{Zn}$ concentrations in grain (Cakmak et al., 2010). Organic source of plant nutrients helps in increasing soil organic matter and improving soil environments as well as meeting a part of nutrients need of crops. Organic matter like FYM also helped in improving micronutrient status of soil. $\mathrm{Zn}$, $\mathrm{Fe}$ and Mn plays very important role in photosynthesis and growth of plants. To obtain high yields without deterioration of soil fertility, it is important to workout optimal combination of fertilizers and manures in the cropping system (Pullicinoa et al., 2009).

In India, increasing productivity of wheat becomes a most to overcome unusual increase in population. In literatures several workers showed the importance of farmyard manure on increasing cereal grain yield. The various physico-chemical processes also mediated the $\mathrm{Zn}$ and $\mathrm{Fe}$ availability in alkaline soils (Meena et al., 2013), i.e. variation in chemical composition of salt affected soils, precipitation-dissolution reactions, adsorption kinetics, transformations of nutrients and crop responses to applied nutrients greatly vary (Katyal and Sharma, 1980; Datta et al., 2013). Application of micronutrients decides the yield potential of crops in deficient soil with low carbon content (Shukla et al., 2014; Ray et al., 2014). Use of FYM and other organic manures produces various types of organic acids during the microbial decomposition and converted the plant nutrients from immobile to mobile in the soil solution (Dotaniya et al., 2016). Combined soil application of micronutrients with FYM significantly enhanced the mustard yield in normal soil (Meena et al., 2006).

Organic manures not only supply micronutrients but also influence the transformation of native micronutrients in soil, thereby enhancing their availability to crops (Pal et al., 2008; Meena et al., 2018). The contributions of soil organic matter to available pools of micronutrients are limited and thus, prone to deficiency of one or more micronutrients especially $\mathrm{Zn}$ and $\mathrm{Fe}$ in salt affected soils (Sharma et al., 2009). Straight or alone application of zinc and Fe fertilizer in normal soil increased the biological produce in mustard (Singh et al., 2010) and in pearl millet (Shukla et al., 2014). In contrast to $\mathrm{Zn}$ fertilizer, soil application of inorganic $\mathrm{Fe}$ salts is ineffective in controlling $\mathrm{Fe}$ deficiency in alkaline soil, except when application rates are as higher as $150 \mathrm{~kg}$ $\mathrm{FeSO}_{4} \mathrm{ha}^{-1}$ under aerobic rice (Pal et al., 2008). Also, the efficacy of foliar spray of $\mathrm{Zn}$ and Fe varies with species and cultivars (Meena et al., 2016). It is well documented that application of $\mathrm{Zn}$ in saline soil increased the its concentration in maize (Rahman et al., 1993) and tomato (Knight et al., 1992) and decreased in case of cucumber leaves (AlHarbi, 1995).

Influences of $\mathrm{Fe}$ application in plants were also inconsistent as $\mathrm{Zn}$ concentration in plants (Achakzai et al., 2010). Ferrous iron $\left(\mathrm{Fe}^{2+}\right)$ content in rice and other plants proved to be a better index of Fe-nutrition status compared to total plant $\mathrm{Fe}$ and chemically extractable 
soil Fe (Katyal and Sharma, 1980; Meena et al., 2016). Limited information is available on the adequate level of $\mathrm{Fe}^{2+}$ in pearl millet and mustard under field conditions which can be used for monitoring purpose. The available information pertaining to ways and means for optimizing $\mathrm{Zn}$ and $\mathrm{Fe}$ requirements to ameliorate deficiencies of these nutrients in various crops have mostly been confined to normal soil conditions. Such information is yet to be generated for pearl millet and mustard cropping sequence grown under salt affected soils. Therefore, the judicious $\mathrm{Zn}$ and $\mathrm{Fe}$ management of plant nutrition in salt affected soils can enhance the food grain production potential of degraded soils. Keeping in view the above facts, this study was initiated to assess the nutrient content and uptake by wheat as influenced by iron and zinc enriched FYM in salt affected soils of Gujarat.

\section{Materials and Methods}

A field experiment was conducted from 201415 to 2015-16, 2016-17 and 2017-18 at Agricultural Research Station, Sardarkrushinagar Dantiwada Agricultural University, Adiya, Gujarat. This experiment consisting of eight treatment combinations viz., $\mathrm{T}_{1}$ : RDF (Based on STV), $\mathrm{T}_{2}: \mathrm{T}_{1}+1.0 \mathrm{t}$ FYM ha ${ }^{-1} ; \mathrm{T}_{3}: \mathrm{T}_{1}+1.5 \mathrm{~kg} \mathrm{Zn} \mathrm{ha}^{-1} ; \mathrm{T}_{4}: \mathrm{T}_{1}+3.0$ $\mathrm{kg} \mathrm{Fe} \mathrm{ha}{ }^{-1} ; \mathrm{T}_{5}: \mathrm{T}_{1}+1.5 \mathrm{~kg} \mathrm{Zn} \mathrm{ha}^{-1}+3.0 \mathrm{~kg} \mathrm{Fe}$ ha $^{-1} ; \mathrm{T}_{6}: \mathrm{T}_{1}+0.5$ t FYM ha ${ }^{-1}$ enriched with $0.75 \mathrm{~kg} \mathrm{Zn} ; \mathrm{T}_{7}: \mathrm{T}_{1}+0.5 \mathrm{t} \mathrm{FYM} \mathrm{ha}^{-1}$ enriched with $1.5 \mathrm{~kg} \mathrm{Fe} ; \mathrm{T}_{8}: \mathrm{T}_{1}+0.5 \mathrm{t} \mathrm{FYM} \mathrm{ha}^{-1}$ enriched with $0.75 \mathrm{~kg} \mathrm{Zn}$ and $1.5 \mathrm{~kg} \mathrm{Fe}$ in randomized block design, which was replicated four times and wheat variety Raj3077 was sown. The soil of the experimental field was loamy sand in texture, alkaline in reaction and soluble salt content under unsafe limit. It was low in organic carbon, medium in available $\mathrm{P}_{2} \mathrm{O}_{5}$ and medium to high available $\mathrm{K}_{2} \mathrm{O}$ and DTPA extrable $\mathrm{Zn}$ and low status of DTPA extrable Fe (Table 1).
Treatment-wise representative grain and straw samples were collected from each plot after harvest. After harvest of the crop, wheat grain/seed and straw samples were taken for analysis. The samples were washed with dilute $0.03 \mathrm{~N} \mathrm{HCl}$, single and double deionized water in a sequence and air dried. Then samples were dried in paper bags at $70^{\circ} \mathrm{C}$ till constant weight in a hot air oven and preserved for further analysis. These samples were ground in a stainless steel Wiley mill to avoid contamination of micronutrients. The processed samples were preserved in airtight polyethylene bags for further analysis.

Dried plant samples (grain and straw) were ground in a stainless steel blade Willey mill and digested in di-acid mixture $\left(\mathrm{HNO}_{3}\right.$ : $\mathrm{HClO}_{4}$ - 4:1) and volume was made with double distilled water (Jackson, 1979). The extract was filtered through Whatman filter paper No. 42. The digested extract of plant samples was used for analysis of phosphorus (Vanadomolybdate yellow colour), potassium (Flame photometric method) and micronutrients (Atomic absorption spectrophotometer). The data of seed yield and straw yield recorded from net plot and converted on hectare basis. The collected data for various parameters were statistically analyzed using Fishers' analysis of variance (ANOVA) technique and the treatments were compared at $5 \%$ level of significance.

\section{Results and Discussion}

\section{Grain and straw yield}

The vital effect of experimental variable was reflected in the final yield of wheat crop. The consequences obtainable in Table 2 make known that application of suggested quantity of fertilizer (120-60-00 NPK kg ha ${ }^{-1}$ ) on the basis of STV + 0.5 t FYM ha ${ }^{-1}$ enriched with $0.75 \mathrm{~kg} \mathrm{Zn}$ and $1.5 \mathrm{~kg} \mathrm{Fe}\left(\mathrm{T}_{8}\right)$ recorded significantly higher grain (4790 kg ha $\left.{ }^{-1}\right)$ and 
straw $\left(7833 \mathrm{~kg} \mathrm{ha}^{-1}\right)$ yields of wheat over $\mathrm{T}_{1}$ (Recommended dose of fertilizer on the basis of STV only) on pooled basis. But, it was at par with $\mathrm{T}_{5}$ on pooled basis in case of grain $\left(4682 \mathrm{~kg} \mathrm{ha}^{-1}\right)$ and straw $\left(7447 \mathrm{~kg} \mathrm{ha}^{-1}\right)$ yield. Cakmak et al., (2008) reported that there is increasing evidence showing that foliar or combined soil foliar application of $\mathrm{Zn}$ fertilizers under field conditions are highly effective and very practical way to maximize uptake and accumulation of $\mathrm{Zn}$ in whole wheat grain, raising concentration up to 60 $\mathrm{mg} \mathrm{Zn} \mathrm{kg}{ }^{-1}$. Increase in yield was due to improved availability of iron and zinc which could be attributed to the formation of stable organometalic complexes with organic matter, especially during the enrichment process to last for a longer time and release the nutrients slowly in the soil system in such a way that the nutrients are protected from fixation and made available to the plant root system throughout the crop growth (Meena et al., 2006). This could be due to the favorite effect of adding FYM as a good source of plant nutrients. Furthermore, FYM acts as a natural soil conditioner which improved soil properties and consequently soil productivity. These results are in accordance with those obtained by More (1994).

\section{Nutrient content}

The data obtained by the influence of different levels of iron and zinc enriched with FYM and without enriched with FYM on nitrogen, phosphorus, potassium content in grain are presented in Table 3. From the perusal of the data, it was observed that $\mathrm{N}, \mathrm{P}$ and $\mathrm{K}$ content in wheat grain show the significant change due to iron and zinc enriched with FYM and without enriched FYM on pooled basis. Significantly higher nitrogen $(2.41 \%)$ and phosphorus $(0.33 \%)$ content in grain was observed by the application of recommended dose of fertilizer (120-60-00 NPK kg ha ${ }^{-1}$ ) on the basis of STV
+ 0.5 t FYM ha $^{-1}$ enriched with $0.75 \mathrm{~kg} \mathrm{Zn}$ and $1.5 \mathrm{~kg} \mathrm{Fe}\left(\mathrm{T}_{8}\right)$ on pooled basis. While, significantly higher potassium content in wheat grain was observed with the application of recommended dose of fertilizer (120-60-00 NPK kg ha ${ }^{-1}$ ) on the basis of STV $+1.0 \mathrm{t}$ FYM ha ${ }^{-1}\left(T_{5}\right)$ on pooled basis. But, nitrogen content was at par with that under $\mathrm{T}_{4}, \mathrm{~T}_{5}, \mathrm{~T}_{6}$ and $\mathrm{T}_{7}$ on pooled basis. However, phosphorus content in wheat grain under $\mathrm{T}_{8}$ was at par treatments $\mathrm{T}_{2}, \mathrm{~T}_{3}, \mathrm{~T}_{4}, \mathrm{~T}_{5}, \mathrm{~T}_{6}$ and $\mathrm{T}_{7}$. Whereas, potassium content $(0.67 \%)$ in wheat grain under $T_{2}$ and $T_{5}$ was at par with treatments $T_{3}$ $\mathrm{T}_{4}, \mathrm{~T}_{5}, \mathrm{~T}_{7}$ and $\mathrm{T}_{8}$ on pooled basis.

From the data presented in Table 4, it was observed that significantly higher Fe content in wheat grain $\left(59.07 \mathrm{mg} \mathrm{kg}^{-1}\right)$ was recorded due to the application of recommended dose of fertilizer (120-60-00 NPK kg ha ${ }^{-1}$ ) on the basis of STV + 0.5 t FYM ha ${ }^{-1}$ enriched with $0.75 \mathrm{~kg} \mathrm{Zn}$ and $1.5 \mathrm{~kg} \mathrm{Fe}\left(\mathrm{T}_{8}\right)$ on pooled basis; which was at par with treatment $\mathrm{T}_{4}\left(\mathrm{~T}_{1}\right.$ $\left.+3.0 \mathrm{~kg} \mathrm{Fe} \mathrm{ha}{ }^{-1}\right), \mathrm{T}_{5}\left(\mathrm{~T}_{1}+1.5 \mathrm{~kg} \mathrm{Zn}+3.0 \mathrm{~kg}\right.$ $\left.\mathrm{Fe} \mathrm{ha}^{-1}\right)$ and $\mathrm{T}_{7}\left(\mathrm{~T}_{1+} 0.5\right.$ t FYM ha ${ }^{-1}$ En. with $1.5 \mathrm{~kg} \mathrm{Fe}$ ). Amongst the different treatments, significant increase in the $\mathrm{Zn}$ content in grain (19.47 mg kg ${ }^{-1}$ ) was observed under treatment which received RDF (based on STV) along with $1.5 \mathrm{~kg} \mathrm{Zn} \mathrm{ha}^{-1}+3.0 \mathrm{~kg} \mathrm{Fe} \mathrm{ha}^{-1}$ in all the years as well as on pooled basis (Table 4); but it was at par with treatment $\mathrm{T}_{8}\left(\mathrm{~T}_{1}+0.5 \mathrm{t}\right.$ FYM ha ${ }^{-1}$ En. with $0.75 \mathrm{~kg} \mathrm{Zn}$ and $1.5 \mathrm{~kg} \mathrm{Fe}$ ).

The data obtained by the influence of different levels of iron and zinc enriched with FYM and without enriched FYM on nitrogen, phosphorus, potassium, $\mathrm{Fe}$ and $\mathrm{Zn}$ contents in wheat straw are presented in Table 5 and Table 6. From the perusal of the data, it was observed that $\mathrm{N}, \mathrm{P}, \mathrm{K}, \mathrm{Fe}$ and $\mathrm{Zn}$ content in wheat straw show significant change due to iron and zinc enriched with FYM and without enriched FYM. Significantly the highest nitrogen (1.09\%), phosphorus $(0.173 \%)$, potassium $(1.32 \%)$, iron $\left(265.2 \mathrm{mg} \mathrm{kg}^{-1}\right)$ and 
zinc $\left(42.75 \mathrm{mg} \mathrm{kg}^{-1}\right)$ contents in wheat straw were observed with the application of RDF (based on STV) along with $0.5 \mathrm{t} \mathrm{FYM} \mathrm{ha}{ }^{-1}$ En. with $0.75 \mathrm{~kg} \mathrm{Zn}$ and $1.5 \mathrm{~kg} F$ on pooled basis. However, nitrogen content in wheat straw was at par with treatments $\mathrm{T}_{5}, \mathrm{~T}_{6}$ and $\mathrm{T}_{7}$; whereas, $\mathrm{P}$ content in wheat straw was at par with treatments $\mathrm{T}_{4}$ and $\mathrm{T}_{7} ; \mathrm{K}$ content in wheat straw was at par with treatments $T_{2}, T_{5}$ and $\mathrm{T}_{7}$. Similarly, iron content in wheat straw was at par with treatments $\mathrm{T}_{4}\left(\mathrm{~T}_{1}+3.0 \mathrm{~kg} \mathrm{Fe}\right.$ $\left.\mathrm{ha}^{-1}\right), \mathrm{T}_{5}\left(\mathrm{~T}_{1}+1.5 \mathrm{~kg} \mathrm{Zn} \mathrm{ha}{ }^{-1}+3.0 \mathrm{~kg} \mathrm{Fe} \mathrm{ha}^{-1}\right)$ and $\mathrm{T}_{7}\left(\mathrm{~T}_{1}+0.5 \mathrm{t}\right.$ FYM ha ${ }^{-1}$ En. with $1.5 \mathrm{~kg}$ $\mathrm{Fe})$ whereas, $\mathrm{Zn}$ content in wheat straw was at par with treatments $\mathrm{T}_{5}\left(\mathrm{~T}_{1}+1.5 \mathrm{~kg} \mathrm{Zn} \mathrm{ha}^{-1}+\right.$ $\left.3.0 \mathrm{~kg} \mathrm{Fe} \mathrm{ha}{ }^{-1}\right)$ and $\mathrm{T}_{6}\left(\mathrm{~T}_{1}+0.5 \mathrm{t} \mathrm{FYM} \mathrm{ha}^{-1}\right.$ En. with $0.75 \mathrm{~kg} \mathrm{Zn).} \mathrm{It} \mathrm{is} \mathrm{well} \mathrm{known} \mathrm{that,}$ during the decomposition of organic matter, macro and micronutrients are incorporated into the soil matrix, allowing the soil to act as a reservoir of these nutrients. These nutrients will be released, to become available for uptake by plants. Otherwise, humus which is the final component of organic matter decomposition, accumulate in the environmental systems to increase moisture retention and nutrient supply potentials of soils (Suganya, and Sivasamy, 2006). The obtained data are confirmed with the results found by Tolba et al., 2003 and Khater et al., 2004, who mentioned that FYM plays an important role for supplying plants by some required nutrients.

Similar results were reported by $\mathrm{Li}$ et al., 2007, where it was suggested that the application of compost increased the organic matter content. By contrast, the results of a long-term field experiment showed that as the soil organic matter contents increased, there were decreases in the mobility of $\mathrm{Cu}, \mathrm{Fe}$, and $\mathrm{Mn}$ in the soil solution, whereas that of $\mathrm{Zn}$ increased (Rutkowska et al., 2014). The mechanisms responsible for these effects were not investigated (Ai et al., 2012), but the variability may be due to the strong buffering capacity of the soil, or the micronutrient levels may depend on soil characteristics, including the $\mathrm{pH}$, texture, organic matter, redox conditions (Keshavarzi et al., 2015) and the type and quantity of oxyhydroxides present, as well as the crop species considered (Marcussen et al., 2009). This difference indicates that the soil properties have significant effects on the absorption of Fe and Zn by plants. According to Campbell, 2009, the critical concentration of $\mathrm{Fe}$ in wheat plants during the vegetative phase is $25 \mathrm{mg} \mathrm{kg}^{-1}$, and the sufficiency concentration range for $\mathrm{Fe}$ in wheat flag leaves during the grain-filling stage is $30-200 \mathrm{mg} \mathrm{kg}^{-1}$. Thus, our results and those of other studies indicate that organic fertilizer enhanced the concentration of $\mathrm{Zn}$ in wheat but decreased the concentration of $\mathrm{Mn}$ compared with the use of a chemical fertilizer (Li et al., 2007). This finding might be explained by the addition of organic material, which increased the soil organic matter content, thereby affecting the transfer of $\mathrm{Zn}$ and $\mathrm{Mn}$ from the soil to plants. In the present study, manure compost increased the available $\mathrm{Zn}$ in the soil, which might be the main reason why the $\mathrm{Zn}$ concentration increased in the wheat straw and grain.

\section{Nutrient uptake}

A perusal of the data presented in Table 7 and Table 8 indicates that the nitrogen, phosphorus, potassium, iron and zinc uptake by wheat grain were significantly influenced by different combinations of iron and zinc enriched with FYM and without enriched FYM. From the perusal of the data, it was observed that maximum nitrogen $(119.82 \mathrm{~kg}$ $\left.\mathrm{ha}^{-1}\right)$, phosphorus (16.25 kg ha $\mathrm{kg}^{-1}$, potassium (31.54 $\mathrm{kg} \mathrm{ha}^{-1}$ ) and iron (305.8 $\left.\mathrm{g} \mathrm{ha}^{-1}\right)$ uptake by wheat grain was recorded under treatment $\mathrm{T}_{8}\left(\mathrm{~T}_{1}+0.5\right.$ t FYM ha $^{-1}$ En. with $0.75 \mathrm{~kg} \mathrm{Zn}$ and $1.5 \mathrm{~kg} \mathrm{Fe}$ ) on pooled basis; but in case of zinc uptake by wheat grain $\left(88.88 \mathrm{~g} \mathrm{ha}^{-1}\right)$ was higher under treatment $\mathrm{T}_{5}\left(\mathrm{~T}_{1}+1.5 \mathrm{~kg} \mathrm{Zn}+\right.$ 
$3.0 \mathrm{~kg} \mathrm{Fe} \mathrm{ha}{ }^{-1}$ ) on pooled basis. However, in case of nitrogen uptake by wheat grain, $\mathrm{T}_{8}$ was at par with treatments $\mathrm{T}_{5}\left(\mathrm{~T}_{1}+1.5 \mathrm{~kg} \mathrm{Zn}\right.$ $\left.\mathrm{ha}^{-1}+3.0 \mathrm{~kg} \mathrm{Fe} \mathrm{ha}{ }^{-1}\right)$; in case of phosphorus uptake by wheat grain, $\mathrm{T}_{8}$ was at par with treatments $\mathrm{T}_{5}$ and $\mathrm{T}_{7}$; in case of potassium uptake by wheat grain, $\mathrm{T}_{8}$ was at par with treatments $\mathrm{T}_{5}$; in case of iron uptake by wheat grain, $\mathrm{T}_{8}$ was at par with treatments $\mathrm{T}_{5}$ and $\mathrm{T}_{7}$ on pooled basis. On the other hand in case of zinc uptake by wheat grain, $\mathrm{T}_{5}$ was at par with treatments $\mathrm{T}_{8}\left(\mathrm{~T}_{1}+0.5\right.$ t FYM ha ${ }^{-1}$ En. with $0.75 \mathrm{~kg} \mathrm{Zn}$ and $1.5 \mathrm{~kg} \mathrm{Fe}$ ) on pooled basis.

Table.1 Physicochemical properties of the experimental soil

\begin{tabular}{|l|l|c|c|c|c|}
\hline \multirow{2}{*}{ Sr. No. } & \multicolumn{2}{|c|}{ Parameters } & \multicolumn{4}{c|}{ Years } \\
\cline { 3 - 6 } & & $\mathbf{2 0 1 4 - 1 5}$ & $\mathbf{2 0 1 5 - 1 6}$ & $\mathbf{2 0 1 6 - 1 7}$ & $\mathbf{2 0 1 7 - 1 8}$ \\
\hline 1. & $\mathrm{pH}$ & 7.70 & 8.12 & 7.64 & 6.98 \\
\hline 2. & $\mathrm{EC}\left(\mathrm{dSm}^{-1}\right)$ & 1.10 & 1.18 & 1.35 & 1.45 \\
\hline 3. & OC $\%$ & 0.31 & 0.25 & 0.38 & 0.26 \\
\hline 4. & Available $\mathrm{P}_{2} \mathrm{O}_{5}(\mathrm{~kg} / \mathrm{ha})$ & 45.87 & 41.25 & 43.25 & 46.58 \\
\hline $\mathbf{5 .}$ & Available $\mathrm{K}_{2} \mathrm{O}(\mathrm{kg} / \mathrm{ha})$ & 241.25 & 285.54 & 356.14 & 266.14 \\
\hline 6. & DTPA extractable Fe $\left(\mathrm{mg} \mathrm{kg}^{-1}\right)$ & 3.78 & 3.95 & 3.51 & 2.25 \\
\hline 7. & DTPA extractable $\mathrm{Zn}\left(\mathrm{mg} \mathrm{kg}^{-1}\right)$ & 0.89 & 1.08 & 0.89 & 0.76 \\
\hline & RDF Based on STV & $\mathbf{1 4 0 : 6 0 : 0}$ & $\mathbf{1 5 0 : 6 0 : 0}$ & $\mathbf{1 4 0 : 6 0 : 0}$ & $\mathbf{1 4 0 : 6 0 : 0}$ \\
\hline
\end{tabular}

Table.2 Effect of iron and zinc enriched with FYM and without enriched FYM on grain and straw yield of wheat (Pooled data 4 years)

\begin{tabular}{|c|c|c|}
\hline Treatments & $\begin{array}{l}\text { Grain yield } \\
\qquad\left(\mathrm{kg} \mathrm{ha}^{-1}\right)\end{array}$ & $\begin{array}{c}\text { Straw yield } \\
\left(\mathrm{kg} \mathrm{ha}^{-1}\right)\end{array}$ \\
\hline$T_{1}$ RDF (Based on STV) & 3781 & 6270 \\
\hline$T_{2} T_{1}+1.0$ t FYM ha $^{-1}$ & 4234 & 6953 \\
\hline $\mathrm{T}_{3} \mathrm{~T}_{1}+1.5 \mathrm{~kg} \mathrm{Zn} \mathrm{ha}^{-1}$ & 4043 & 6571 \\
\hline $\mathrm{T}_{4} \mathrm{~T}_{1}+3.0 \mathrm{~kg} \mathrm{Fe} \mathrm{ha}{ }^{-1}$ & 4189 & 6666 \\
\hline$T_{5} T_{1}+1.5 \mathrm{~kg} \mathrm{Zn} \mathrm{ha}^{-1}+3.0 \mathrm{~kg} \mathrm{Fe} \mathrm{ha}^{-1}$ & 4682 & 7447 \\
\hline $\mathrm{T}_{6} \mathrm{~T}_{1}+0.5 \mathrm{t}$ FYM ha ${ }^{-1}$ En. with $0.75 \mathrm{~kg} \mathrm{Zn}$ & 4264 & 6883 \\
\hline $\mathrm{T}_{7} \mathrm{~T}_{1}+0.5 \mathrm{t} \mathrm{FYM} \mathrm{ha}^{-1} \mathrm{En}$. with $1.5 \mathrm{~kg} \mathrm{Fe}$ & 4516 & 7140 \\
\hline $\mathrm{T}_{8} \mathrm{~T}_{1}+0.5 \mathrm{t}$ FYM ha ${ }^{-1} \mathrm{En}$. with $0.75 \mathrm{~kg} \mathrm{Zn}$ and $1.5 \mathrm{~kg} \mathrm{Fe}$ & 4790 & 7833 \\
\hline S.Em. \pm & 94 & 153 \\
\hline C.D. at $5 \%$ & 266 & 431 \\
\hline C.V. \% & 8.75 & 8.77 \\
\hline $\mathbf{Y} \times \mathbf{T}$ & NS & NS \\
\hline
\end{tabular}


Table.3 Effect of iron and zinc enriched with FYM and without enriched FYM on nutrients content in wheat grain (Pooled data 4 years)

\begin{tabular}{|c|c|c|c|}
\hline \multirow[t]{2}{*}{ Treatments } & \multicolumn{3}{|c|}{ Nutrients content in wheat grain $(\%)$} \\
\hline & Nitrogen & Phosphorus & Potassium \\
\hline $\mathrm{T}_{1}$ RDF (Based on STV) & 2.14 & 0.27 & 0.61 \\
\hline $\mathrm{T}_{2} \mathrm{~T}_{1}+1.0 \mathrm{t}_{\mathrm{FYM} \mathrm{ha}}{ }^{-1}$ & 2.20 & 0.33 & 0.67 \\
\hline $\mathrm{T}_{3} \mathrm{~T}_{1}+1.5 \mathrm{~kg} \mathrm{Zn} \mathrm{ha}{ }^{-1}$ & 2.23 & 0.33 & 0.63 \\
\hline $\mathrm{T}_{4} \mathrm{~T}_{1}+3.0 \mathrm{~kg} \mathrm{Fe} \mathrm{ha}^{-1}$ & 2.32 & 0.32 & 0.63 \\
\hline $\mathrm{T}_{5} \mathrm{~T}_{1}+1.5 \mathrm{~kg} \mathrm{Zn} \mathrm{ha}^{-1}+3.0 \mathrm{~kg} \mathrm{Fe} \mathrm{ha}^{-1}$ & 2.33 & 0.31 & 0.67 \\
\hline $\mathrm{T}_{6} \mathrm{~T}_{1}+0.5 \mathrm{t}$ FYM ha ${ }^{-1}$ En. with $0.75 \mathrm{~kg} \mathrm{Zn}$ & 2.32 & 0.32 & 0.61 \\
\hline $\mathrm{T}_{7} \mathrm{~T}_{1}+0.5 \mathrm{t} \mathrm{FYM} \mathrm{ha}^{-1} \mathrm{En}$. with $1.5 \mathrm{~kg} \mathrm{Fe}$ & 2.38 & 0.33 & 0.63 \\
\hline $\mathrm{T}_{8} \mathrm{~T}_{1}+0.5 \mathrm{t} \mathrm{FYM} \mathrm{ha}^{-1} \mathrm{En}$. with $0.75 \mathrm{~kg} \mathrm{Zn}$ and $1.5 \mathrm{~kg} \mathrm{Fe}$ & 2.41 & 0.33 & 0.66 \\
\hline S.Em. \pm & 0.05 & 0.01 & 0.02 \\
\hline C.D. at $5 \%$ & 0.15 & 0.03 & 0.05 \\
\hline C.V. \% & 9.46 & 14.49 & 10.10 \\
\hline $\mathbf{Y} \times \mathbf{T}$ & NS & NS & NS \\
\hline
\end{tabular}

Table.4 Effect of iron and zinc enriched with FYM and without enriched FYM on micronutrients content in wheat grain (Pooled data 4 years)

\begin{tabular}{|c|c|c|}
\hline Treatments & $\begin{array}{c}\text { Fe } \\
\left(\mathrm{mg} \mathrm{kg}^{-1}\right)\end{array}$ & $\begin{array}{c}\mathrm{Zn} \\
\left(\mathrm{mg} \mathrm{kg}^{-1}\right)\end{array}$ \\
\hline$T_{1}$ RDF (Based on STV) & 45.57 & 13.91 \\
\hline $\mathrm{T}_{2} \mathrm{~T}_{1}+1.0 \mathrm{t} \mathrm{FYM} \mathrm{ha}^{-1}$ & 48.94 & 15.35 \\
\hline$T_{3} T_{1}+1.5 \mathrm{~kg} \mathrm{Zn} \mathrm{ha}^{-1}$ & 49.05 & 16.79 \\
\hline $\mathrm{T}_{4} \mathrm{~T}_{1}+3.0 \mathrm{~kg} \mathrm{Fe} \mathrm{ha}{ }^{-1}$ & 54.07 & 15.02 \\
\hline $\mathrm{T}_{5} \mathrm{~T}_{1}+1.5 \mathrm{~kg} \mathrm{Zn} \mathrm{ha}^{-1}+3.0 \mathrm{~kg} \mathrm{Fe} \mathrm{ha}^{-1}$ & 57.42 & 19.47 \\
\hline $\mathrm{T}_{6} \mathrm{~T}_{1}+0.5 \mathrm{t}$ FYM ha ${ }^{-1}$ En. with $0.75 \mathrm{~kg} \mathrm{Zn}$ & 47.95 & 17.63 \\
\hline $\mathrm{T}_{7} \mathrm{~T}_{1}+0.5 \mathrm{t} \mathrm{FYM} \mathrm{ha}^{-1}$ En. with $1.5 \mathrm{~kg} \mathrm{Fe}$ & 56.92 & 15.40 \\
\hline 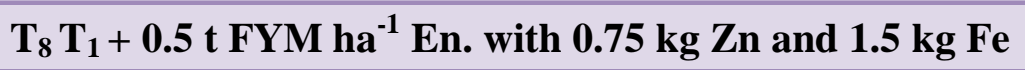 & 59.07 & 18.33 \\
\hline S.Em. \pm & 1.89 & 0.48 \\
\hline C.D. at $5 \%$ & 5.57 & 1.35 \\
\hline C.V. $\%$ & 9.46 & 11.66 \\
\hline $\mathbf{Y} \times \mathbf{T}$ & NS & NS \\
\hline
\end{tabular}


Table.5 Effect of iron and zinc enriched with FYM and without enriched FYM on nutrients content in wheat straw (Pooled data 4 years)

\begin{tabular}{|c|c|c|c|}
\hline \multirow[t]{2}{*}{ Treatments } & \multicolumn{3}{|c|}{ Nutrients content in wheat straw (\%) } \\
\hline & Nitrogen & Phosphorus & Potassium \\
\hline$T_{1}$ RDF (Based on STV) & 0.90 & 0.143 & 1.12 \\
\hline$T_{2} T_{1}+1.0$ t FYM ha $^{-1}$ & 0.95 & 0.153 & 1.27 \\
\hline$T_{3} T_{1}+1.5 \mathrm{~kg} \mathrm{Zn} \mathrm{ha}^{-1}$ & 0.97 & 0.153 & 1.15 \\
\hline $\mathrm{T}_{4} \mathrm{~T}_{1}+3.0 \mathrm{~kg} \mathrm{Fe} \mathrm{ha}^{-1}$ & 0.96 & 0.157 & 1.19 \\
\hline $\mathrm{T}_{5} \mathrm{~T}_{1}+1.5 \mathrm{~kg} \mathrm{Zn} \mathrm{ha}^{-1}+3.0 \mathrm{~kg} \mathrm{Fe} \mathrm{ha}^{-1}$ & 1.03 & 0.150 & 1.28 \\
\hline $\mathrm{T}_{6} \mathrm{~T}_{1+} 0.5 \mathrm{t}$ FYM ha ${ }^{-1}$ En. with $0.75 \mathrm{~kg} \mathrm{Zn}$ & 0.99 & 0.152 & 1.25 \\
\hline $\mathrm{T}_{7} \mathrm{~T}_{1+} 0.5 \mathrm{t}$ FYM ha ${ }^{-1}$ En. with $1.5 \mathrm{~kg} \mathrm{Fe}$ & 1.04 & 0.166 & 1.27 \\
\hline $\mathrm{T}_{8} \mathrm{~T}_{1}+0.5 \mathrm{t}$ FYM ha ${ }^{-1} \mathrm{En}$. with $0.75 \mathrm{~kg} \mathrm{Zn}$ and $1.5 \mathrm{~kg} \mathrm{Fe}$ & 1.09 & 0.173 & 1.32 \\
\hline S.Em. \pm & 0.04 & 0.006 & 0.03 \\
\hline C.D. at $5 \%$ & 0.11 & 0.018 & 0.09 \\
\hline C.V.\% & 10.86 & 16.22 & 10.89 \\
\hline$Y \times T$ & NS & NS & NS \\
\hline
\end{tabular}

Table.6 Effect of iron and zinc enriched with FYM and without enriched FYM on micronutrients content in wheat straw (Pooled data 4 years)

\begin{tabular}{|c|c|c|}
\hline Treatments & $\begin{array}{c}\mathrm{Fe} \\
\left(\mathrm{mg} \mathrm{kg}^{-1}\right)\end{array}$ & $\begin{array}{c}\mathrm{Zn} \\
\left(\mathrm{mg} \mathrm{kg}^{-1}\right)\end{array}$ \\
\hline$T_{1}$ RDF (Based on STV) & 204.8 & 28.50 \\
\hline $\mathrm{T}_{2} \mathrm{~T}_{1}+1.0 \mathrm{t} \mathrm{FYM} \mathrm{ha}^{-1}$ & 219.9 & 32.28 \\
\hline $\mathrm{T}_{3} \mathrm{~T}_{1}+1.5 \mathrm{~kg} \mathrm{Zn} \mathrm{ha}^{-1}$ & 230.4 & 34.04 \\
\hline $\mathrm{T}_{4} \mathrm{~T}_{1}+3.0 \mathrm{~kg} \mathrm{Fe} \mathrm{ha}^{-1}$ & 252.6 & 31.73 \\
\hline $\mathrm{T}_{5} \mathrm{~T}_{1}+1.5 \mathrm{~kg} \mathrm{Zn} \mathrm{ha}^{-1}+3.0 \mathrm{~kg} \mathrm{Fe} \mathrm{ha}^{-1}$ & 260.3 & 40.27 \\
\hline $\mathrm{T}_{6} \mathrm{~T}_{1}+0.5 \mathrm{t}$ FYM ha ${ }^{-1}$ En. with $0.75 \mathrm{~kg} \mathrm{Zn}$ & 227.1 & 42.06 \\
\hline $\mathrm{T}_{7} \mathrm{~T}_{1}+0.5 \mathrm{t} \mathrm{FYM} \mathrm{ha}^{-1}$ En. with $1.5 \mathrm{~kg} \mathrm{Fe}$ & 259.3 & 37.92 \\
\hline $\mathrm{T}_{8} \mathrm{~T}_{1}+0.5 \mathrm{t}$ FYM ha ${ }^{-1} \mathrm{En}$. with $0.75 \mathrm{~kg} \mathrm{Zn}$ and $1.5 \mathrm{~kg} \mathrm{Fe}$ & 265.2 & 42.75 \\
\hline S.Em. \pm & 5.9 & 1.19 \\
\hline C.D. at $5 \%$ & 16.6 & 3.35 \\
\hline C.V. $\%$ & 9.81 & 13.13 \\
\hline $\mathbf{Y} \mathbf{x} \mathbf{T}$ & NS & NS \\
\hline
\end{tabular}


Table.7 Effect of iron and zinc enriched with FYM and without enriched FYM on nutrients uptake by wheat grain (Pooled data 4 years)

\begin{tabular}{|c|c|c|c|}
\hline \multirow[t]{2}{*}{ Treatments } & \multicolumn{3}{|c|}{$\begin{array}{l}\text { Nutrients uptake by wheat grain } \\
\qquad\left(\mathrm{kg} \mathrm{ha}^{-1}\right)\end{array}$} \\
\hline & Nitrogen & Phosphorus & Potassium \\
\hline$T_{1}$ RDF (Based on STV) & 81.15 & 10.34 & 23.92 \\
\hline$T_{2} T_{1}+1.0$ t FYM ha ${ }^{-1}$ & 93.20 & 14.24 & 28.77 \\
\hline $\mathrm{T}_{3} \mathrm{~T}_{1}+1.5 \mathrm{~kg} \mathrm{Zn} \mathrm{ha}^{-1}$ & 90.66 & 13.38 & 25.54 \\
\hline $\mathrm{T}_{4} \mathrm{~T}_{1}+3.0 \mathrm{~kg} \mathrm{Fe} \mathrm{ha}{ }^{-1}$ & 97.52 & 13.78 & 25.31 \\
\hline $\mathrm{T}_{5} \mathrm{~T}_{1}+1.5 \mathrm{~kg} \mathrm{Zn} \mathrm{ha}^{-1}+3.0 \mathrm{~kg} \mathrm{Fe} \mathrm{ha}^{-1}$ & 111.22 & 15.01 & 30.38 \\
\hline $\mathrm{T}_{6} \mathrm{~T}_{1}+0.5 \mathrm{t}$ FYM ha ${ }^{-1}$ En. with $0.75 \mathrm{~kg} \mathrm{Zn}$ & 99.62 & 13.67 & 25.65 \\
\hline $\mathrm{T}_{7} \mathrm{~T}_{1}+0.5 \mathrm{t} \mathrm{FYM} \mathrm{ha}^{-1}$ En. with $1.5 \mathrm{~kg} \mathrm{Fe}$ & 108.01 & 15.35 & 27.96 \\
\hline $\mathrm{T}_{8} \mathrm{~T}_{1}+0.5 \mathrm{t} \mathrm{FYM} \mathrm{ha}^{-1} \mathrm{En}$. with $0.75 \mathrm{~kg} \mathrm{Zn}$ and $1.5 \mathrm{~kg} \mathrm{Fe}$ & 119.82 & 16.25 & 31.54 \\
\hline S.Em. \pm & 3.47 & 0.64 & 0.92 \\
\hline C.D. at $5 \%$ & 9.79 & 1.79 & 2.60 \\
\hline C.V. \% & 13.88 & 18.19 & 13.47 \\
\hline $\mathbf{Y} \mathbf{X} \mathbf{T}$ & NS & NS & NS \\
\hline
\end{tabular}

Table.8 Effect of iron and zinc enriched with FYM and without enriched FYM on micronutrients uptake by wheat grain (Pooled data 4 years)

\begin{tabular}{|c|c|c|}
\hline Treatments & $\begin{array}{c}\text { Fe } \\
\left(\mathrm{g} \mathrm{ha}^{-1}\right)\end{array}$ & $\begin{array}{c}\mathrm{Zn} \\
\left(\mathrm{g} \mathrm{ha}^{-1}\right)\end{array}$ \\
\hline$T_{1}$ RDF (Based on STV) & 179.2 & 52.65 \\
\hline $\mathrm{T}_{2} \mathrm{~T}_{1}+1.0 \mathrm{t}$ FYM ha ${ }^{-1}$ & 212.7 & 65.15 \\
\hline $\mathrm{T}_{3} \mathrm{~T}_{1}+1.5 \mathrm{~kg} \mathrm{Zn} \mathrm{ha}^{-1}$ & 206.9 & 68.44 \\
\hline $\mathrm{T}_{4} \mathrm{~T}_{1}+3.0 \mathrm{~kg} \mathrm{Fe} \mathrm{ha}^{-1}$ & 242.7 & 62.46 \\
\hline$T_{5} T_{1}+1.5 \mathrm{~kg} \mathrm{Zn} \mathrm{ha}^{-1}+3.0 \mathrm{~kg} \mathrm{Fe} \mathrm{ha}^{-1}$ & 284.0 & 88.88 \\
\hline $\mathrm{T}_{6} \mathrm{~T}_{1}+0.5 \mathrm{t} \mathrm{FYM} \mathrm{ha}^{-1} \mathrm{En}$. with $0.75 \mathrm{~kg} \mathrm{Zn}$ & 218.1 & 74.85 \\
\hline $\mathrm{T}_{7} \mathrm{~T}_{1}+0.5 \mathrm{t} \mathrm{FYM} \mathrm{ha}^{-1} \mathrm{En}$. with $1.5 \mathrm{~kg} \mathrm{Fe}$ & 282.1 & 69.67 \\
\hline$T_{8} T_{1}+0.5$ t FYM ha ${ }^{-1}$ En. with $0.75 \mathrm{~kg} \mathrm{Zn}$ and $1.5 \mathrm{~kg} \mathrm{Fe}$ & 305.8 & 88.54 \\
\hline S.Em. \pm & 9.6 & 3.45 \\
\hline C.D. at $5 \%$ & 27.0 & 9.73 \\
\hline C.V. \% & 15.9 & 19.37 \\
\hline $\mathbf{Y} \times \mathbf{T}$ & NS & NS \\
\hline
\end{tabular}


Table.9 Effect of iron and zinc enriched with FYM and without enriched FYM on nutrients uptake by wheat straw (Pooled data 4 years)

\begin{tabular}{|c|c|c|c|}
\hline \multirow[t]{2}{*}{ Treatments } & \multicolumn{3}{|c|}{$\begin{array}{l}\text { Nutrients uptake by wheat straw } \\
\qquad\left(\mathrm{kg} \mathrm{ha}^{-1}\right)\end{array}$} \\
\hline & Nitrogen & Phosphorus & Potassium \\
\hline$T_{1}$ RDF (Based on STV) & 55.60 & 9.15 & 70.5 \\
\hline $\mathrm{T}_{2} \mathrm{~T}_{1}+1.0 \mathrm{t}$ FYM ha ${ }^{-1}$ & 65.58 & 10.91 & 89.0 \\
\hline $\mathrm{T}_{3} \mathrm{~T}_{1}+1.5 \mathrm{~kg} \mathrm{Zn} \mathrm{ha}{ }^{-1}$ & 62.85 & 10.30 & 75.5 \\
\hline $\mathrm{T}_{4} \mathrm{~T}_{1}+3.0 \mathrm{~kg} \mathrm{Fe} \mathrm{ha}{ }^{-1}$ & 63.64 & 10.83 & 80.0 \\
\hline$T_{5} T_{1}+1.5 \mathrm{~kg} \mathrm{Zn} \mathrm{ha}^{-1}+3.0 \mathrm{~kg} \mathrm{Fe} \mathrm{ha}^{-1}$ & 76.56 & 11.42 & 95.7 \\
\hline $\mathrm{T}_{6} \mathrm{~T}_{1+} 0.5 \mathrm{t}$ FYM ha ${ }^{-1}$ En. with $0.75 \mathrm{~kg} \mathrm{Zn}$ & 67.65 & 10.80 & 86.7 \\
\hline $\mathrm{T}_{7} \mathrm{~T}_{1+} 0.5 \mathrm{t} \mathrm{FYM} \mathrm{ha}^{-1} \mathrm{En}$. with $1.5 \mathrm{~kg} \mathrm{Fe}$ & 74.33 & 12.33 & 90.8 \\
\hline $\mathrm{T}_{8} \mathrm{~T}_{1}+0.5 \mathrm{t}$ FYM ha ${ }^{-1} \mathrm{En}$. with $0.75 \mathrm{~kg} \mathrm{Zn}$ and $1.5 \mathrm{~kg} \mathrm{Fe}$ & 84.97 & 14.02 & 104.2 \\
\hline 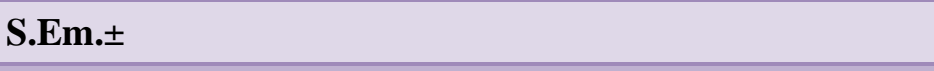 & 3.60 & 0.55 & 2.9 \\
\hline C.D. at $5 \%$ & 10.58 & 1.54 & 8.3 \\
\hline C.V. \% & 14.11 & 19.46 & 13.54 \\
\hline $\mathbf{Y} \times \mathbf{T}$ & NS & NS & NS \\
\hline
\end{tabular}

Table.10 Effect of iron and zinc enriched with FYM and without enriched FYM on micronutrient uptake by wheat straw (Pooled data 4 years)

\begin{tabular}{|c|c|c|}
\hline Treatments & $\begin{array}{c}\text { Fe } \\
\left(\mathrm{g} \mathrm{ha}^{-1}\right)\end{array}$ & $\begin{array}{c}\mathbf{Z n} \\
\left(\mathrm{g} \mathrm{ha}^{-1}\right)\end{array}$ \\
\hline$T_{1}$ RDF (Based on STV) & 1280 & 177.4 \\
\hline$T_{2} T_{1}+1.0$ t FYM ha $^{-1}$ & 1529 & 220.6 \\
\hline $\mathrm{T}_{3} \mathrm{~T}_{1}+1.5 \mathrm{~kg} \mathrm{Zn \textrm {ha } ^ { - 1 }}$ & 1521 & 221.8 \\
\hline $\mathrm{T}_{4} \mathrm{~T}_{1}+3.0 \mathrm{~kg} \mathrm{Fe} \mathrm{ha}{ }^{-1}$ & 1700 & 213.2 \\
\hline $\mathrm{T}_{5} \mathrm{~T}_{1}+1.5 \mathrm{~kg} \mathrm{Zn} \mathrm{ha}{ }^{-1}+3.0 \mathrm{~kg} \mathrm{Fe} \mathrm{ha}^{-1}$ & 1948 & 290.4 \\
\hline $\mathrm{T}_{6} \mathrm{~T}_{1}+0.5 \mathrm{t} \mathrm{FYM} \mathrm{ha}{ }^{-1} \mathrm{En}$. with $0.75 \mathrm{~kg} \mathrm{Zn}$ & 1567 & 282.0 \\
\hline $\mathrm{T}_{7} \mathrm{~T}_{1}+0.5 \mathrm{t} \mathrm{FYM} \mathrm{ha}^{-1} \mathrm{En}$. with $1.5 \mathrm{~kg} \mathrm{Fe}$ & 1873 & 270.2 \\
\hline $\mathrm{T}_{8} \mathrm{~T}_{1}+0.5 \mathrm{t}$ FYM ha ${ }^{-1}$ En. with $0.75 \mathrm{~kg} \mathrm{Zn}$ and $1.5 \mathrm{~kg} \mathrm{Fe}$ & 2098 & 332.7 \\
\hline S.Em. \pm & 58 & 9.9 \\
\hline C.D. at $5 \%$ & 164 & 27.9 \\
\hline C.V. \% & 13.81 & 15.75 \\
\hline $\mathbf{Y} \mathbf{x} \mathbf{T}$ & NS & NS \\
\hline
\end{tabular}


A perusal of the data presented in Table 9 and Table 10 indicates that the nitrogen, phosphorus, potassium, iron and zinc uptake by wheat straw was significantly influenced by different combinations of iron and zinc enriched with FYM and without enriched FYM. From the perusal of the data, it was observed that significantly higher nitrogen (84.97 kg ha ${ }^{-1}$ ), phosphorus (14.02 kg ha-1), potassium (104.2 $\left.\mathrm{kg} \mathrm{ha}^{-1}\right)$, iron (2098 $\mathrm{g} \mathrm{ha}^{-1}$ ) and zinc (332.7 $\mathrm{g} \mathrm{ha}^{-1}$ ) uptake by wheat straw was recorded under treatment $\mathrm{T}_{8}\left(\mathrm{~T}_{1}+0.5 \mathrm{t}\right.$ FYM ha ${ }^{-1}$ En. with $0.75 \mathrm{~kg} \mathrm{Zn}$ and $1.5 \mathrm{~kg} \mathrm{Fe}$ ) on pooled basis. However, in case nitrogen and $\mathrm{Fe}$ uptake by wheat straw, $\mathrm{T}_{8}$ was at par with treatments $T_{5}$ on pooled basis.

The maximum uptake of all these nutrients in the wheat grain and straw were recorded when nutrient were applied with the application of RDF along with $+0.5 \mathrm{t}$ FYM $\mathrm{ha}^{-1}$ enriched with $0.75 \mathrm{~kg} \mathrm{Zn}$ and $1.5 \mathrm{~kg} \mathrm{Fe}$. Increase in uptake in these nutrients may be due to the increased in fertility levels attributed to the better availability of nutrients and their transport to the plant from the soil. Similar results have been reported earlier (Gupta and Handore, 2009; Khan et al., 2009). The beneficial effect of application of higher amounts of organic manure through FYM is not only favored the greater availability of throughout crop growth, fertilizer into different stages resulting in significant improvement in nutrient content and uptake. This result corroborates the finding of Zhang et al., 2010. Since uptake of nutrient is a function of concentration of nutrient and yield/ha at higher fertility levels, nutrient absorption increased resulting in a luxuriant growth and accumulation of more nutrients in the grain and straw that might have increased the uptake of nitrogen, phosphorus, and potassium. This might be the main reason behind the higher production of grain and straw yield with maximum nutrient uptake in the crop.

\section{References}

Achakzai, A.K.K., S.A. Kayani and A. Hanif (2010). Effect of salinity on uptake of micronutrients in sunflower at early vegetative stage. Pak. J. Bot., 42: 129139.

Ai, C., Liang, G.Q., Sun, J.W., Wang, X.B., Zhou, W. (2012). Responses of extracellular enzyme activities and microbial community in both the rhizosphere and bulk soil to long-term fertilization practices in a fluvo-aquic soil. Geoderma, 173: 330-338.

Al-Harbi, A.R. (1995). Growth and nutrient composition of tomato and cucumber seedlings as affected by sodium chloride salinity and supplemented calcium. J. Plant Nutr., 18:1403-1408.

Anonymous, (2017). Directorate of Economics \& Statistics, Department of Agriculture, Cooperation \& Farmers Welfare, New Delhi, 2017.

Cakmak, I. (2008). Enrichment of cereal grains with zinc: agronomic or genetic biofortification. Plant and Soil, 302(1,2):1-17.

Cakmak, I., Kutman, U.B. (2017). Agronomic biofortification of cereals with zinc: a review. European Journal of Soil Science, 69(1):172-180.

Cakmak, I., Pfeiffer, W.H. and McClafferty, B. (2010). Biofortification of durum wheat with zinc and iron. Cer. Chem. 87: 1020.

Campbell, C.R. (2009). Reference sufficiency ranges for plant analysis in the southern region of the United States. Southern Cooperative Series Bulletin No. 394. Raleigh, NC: North Carolina Department of Agriculture and Consumer Services Agronomy Division.

Datta, S.P., Meena, B.L. and Rattan, R.K. (2013). Development of a computer program for calculating metal ion activity using Baker soil test. J. Indian Soc. Soil Sci., 61: 47-50.

Dotaniya, M.L., Datta, S.C., Biswas, D.R., 
Dotaniya, C.K., Meena, B.L., Rajendiran, S., Regar, K.L. and Manju, L. (2016). Use of sugarcane industrial by-products for improving sugarcane productivity and soil health. Int. J. Recycl. Org. Waste Agricult., 5: 185194.

Gul, Hasina., Said, Ahmad., Saeed, Beena., Fida, Mohammad. and Ahmad, Ijaz. (2011). Effect of foliar application of nitrogen, potassium and zinc on wheat growth. Journal of Agricultural and Biological Science, 6(4):56-58.

Gupta, S. and Handore, K. (2009). Direct and residual effect of zinc and zinc amended organic manures on the zinc nutrition of field crop. Int J Agric Sci 1: 26-29.

Katyal, J.C. and B.D. Sharma (1980). A new technique of plant analysis to resolve iron chlorosis. Plant Soil, 55: 105-119.

Katyal, J.C. and B.D. Sharma (1980). A new technique of plant analysis to resolve iron chlorosis. Plant Soil, 55: 105-119.

Keshavarzi, B., Moore, F., Ansari, M., Mehr, M.R., Kaabi, H. and Kermani M. (2015). Macronutrients and trace metals in soil and food crops of Isfahan Province, Iran. Environmental Monitoring and Assessment, 187: 4113.

Khan, G.A., Muhammad, M.Q., Muhammad, J. and Hussain. T.F. (2009). Nutrient uptake, growth and yield of wheat (Triticum aestivum) as affected by zinc application rates. Int $\mathbf{J}$ Agric Bio 11: 389-396.

Khater, E.A., Ibrahim, S.B. and Awadalla, A.A. (2004). Utilization of some form organic wastes for improving soil productivity the newly reclaimed areas at El-Fayoum governorate Egypt. Egypt. J. Soil Sci., 44(3): 333-354.

Knight, S.L., Rogers, R.B., Smith, M.A.L. and Spomer, L.A. (1992). Effects of $\mathrm{NaCl}$ salinity on miniature dwarf tomato 'Micro-Tom': I. Growth analyses and nutrient composition. J. Plant Nutr., 15: 2315-2327.

Li, B.Y., Zhou, D.M., Cang, L., Zhang, H.L., Fan, X.H. and Qin, S.W. (2007). Soil micronutrient availability to crops as affected by long-term inorganic and organic fertilizer applications. Soil \& Tillage Research, 96: 166-173.

Marcussen, H., Holm, P.E., Strobel, B.W. and Hansen, H.C.B. (2009). Nickel Sorption to Goethite and Montmorillonite in Presence of Citrate. Environmental Science \& Technology, 43: 1122-1127.

Meena, B.L., Fagodiya, R. K., Prajapat, K., Dotaniya, M.L., Kaledhonkar, M.J., Sharma, P. C., Meena, R.S., Mitran, T. and Kumar, S. (2018). Legume Green Manuring: An Option for Soil Sustainability. In: Meena R. et al., (eds) Legumes for Soil Health and Sustainable Management. Springer, Singapore, pp. 387-408.

Meena, B.L., Rattan, R.K. and Datta, S.P. (2013). Efficacy of seed treatment in ameliorating iron deficiency in aerobic rice on a calcareous soil. J. Indian Soc. Soil Sci., 61: 147-152.

Meena, B.L., Rattan, R.K., Datta, S.P. and Meena, M.C. (2016). Effect of iron application on iron nutrition of aerobic rice grown in different soils. J. Environ. Biol., 37: 1377-1383.

Meena, M.C., Patel, K.P. and Rathod, D.D. (2006). Effect of $\mathrm{Zn}$ and $\mathrm{Fe}$ enriched FYM on mustard yield and micronutrients availability in loamy sand soil of Anand. J. Indian Soc. Soil Sci., 54: 495-499.

More, S.D. (1994). Effect of farm wastes and organic irrigated with saline water. J. Appl. Sci. Res., manure on soil properties, nutrient availability and 3(6): 431-436. Yields of rice and wheat grown on sodic Vertsoils. J. Ind. Soc. Sci., 46: 253.

Navrang, S. and Tomar, G.S. (2016). Effect of integrated use of FYM and urea on yield, nutrient uptake and protein content of wheat (Triticum aestivum L.) Supplement on Agronomy. 11(1):663668.

Pal, S., Datta, S.P., Rattan, R.K. and Singh, A.K. (2008). Diagnosis and 
amelioration of iron deficiency under aerobic rice. J. Plant Nutr., 31: 919-940.

Pullicinoa, D.S., Massaccesia, L., Dixonb, R.B. and Gigliottia, G. (2009). Organic matter dynamics in a compost- amended anthropogenic landfill capping-soil. Europ J Soil Sci 61: 35-47.

Rahman, S., Vance, G.F. and Munn, L.C. (1993). Salinity induced effects on the nutrient status of soil, corn leaves and kernels. Comm. Soil. Sci. Plant Anal., 24: 2251-2269.

Ray, P., Meena, B.L. and Nath, C.P. (2014). Management of coastal soils for improving soil quality and productivity. Pop. Kheti, 2:95-99.

Rutkowska, B., Szulc, W., Sosulski, T. and Stepien, W. (2014). Soil micronutrient availability to crops affected by longterm inorganic and organic fertilizer applications. Plant Soil and Environment, 60: 198-203.

Sharma, B.D., Kumar, R., Singh, B. and Sethi, M. (2009). Micronutrients distribution in salt-affected soils of the Punjab in relation to soil properties. Arch. Agron. Soil Sci., 55: 367-377.

Shivay Y.S., Prasad, R., Shukla, A.K. and Das, S. (2014). Zinc Management" Text Book of Plant Nutrient Management by Prasad et al., First Edition, 182-187.

Shukla, A.K., Tiwari, P.K. and Prakash, C. (2014). Micronutrients deficiencies vis- a-vis food and nutritional security of India. Indian J. Fert., 10: 94-112.

Singh, S.K., Mishra, V.K., Srivastava, U.K. and Kumar, A. (2012). Impact of irrigation levels on growth, yield and quality of wheat (Triticum aestivum L.). Environ Ecol 30: 72-77.

Singh, Y., Singh, T., Singh, U.N. and Rajput, P.K. (2010). Effect of nutrient management on yield, quality and economics of irrigated Indian mustard (Brassica juncea). Indian J. Agr. Sci., 80: 691-694.

Suganya, S. and Sivasamy, R. (2006). Moisture Retention and Cation Exchange Capacity of Sandy Soil as Influenced by Soil Additives. J. Appl. Sci. Res., 2: 949-951.

Tolba, M.H., Baddour, G.A. and El-Ghamry, A.M. (2003). Effect of different sources of organic manures on eggplant (Solanum melongena, L.) and some soil properties. J. Agric. Sci. Mansoura Unive., Special Issue, Scientific Symposium on "problems of soils and water in Dakohlia and Domietta Governorayes" March, 18: 127-135.

Zhang, S.R., Yue, Q.C., Xin, P.S., Qin, P.Z., Romheld, F.S. and Chunqin, V.Z. (2010). Influence of long-term nitrogen fertilization on micronutrient density in grain of winter wheat (Triticum aestivum L.). J Cer. Sci. 51: 165-170.

\section{How to cite this article:}

Malav, J.K., N.N. Salvi, J.K. Patel, J.R. Jat, S. Kumar, R.P. Pavaya, B.T. Patel and Patel, V.R. 2019. Nutrient Content and Uptake by Wheat (Triticum aestivum L) as Influenced by Iron and Zinc Enriched FYM in Salt Affected Soils of Gujarat. Int.J.Curr.Microbiol.App.Sci. 8(06): 2970-2982. doi: https://doi.org/10.20546/ijcmas.2019.806.355 